ENTREPRENEURSHIP AND SUSTAINABILITY ISSUES

ISSN 2345-0282 (online) http://jssidoi.org/jesi/

2019 Volume 7 Number 2 (December)

http://doi.org/10.9770/jesi.2020.7.2(58)

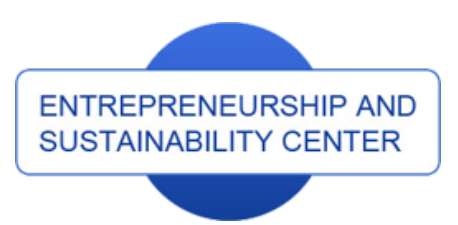

Publisher

http://jssidoi.org/esc/home

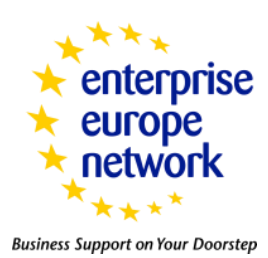

CASPA

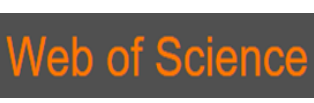

I Clarivate

Analytics

\title{
APPLICATION OF HADI-CYCLE FOR PROVIDING SUSTAINABILITY OF PROCESSES OF KNOWLEDGE AND INNOVATION*
}

\author{
Zhanna Mingaleva ${ }^{1}$, Lyudmila Deputatova ${ }^{2}$, Nikolay Akatov ${ }^{3}$, Yurii Starkov ${ }^{4}$, \\ Elena Mitrofanova ${ }^{5}$ \\ 1,2,3,4 Perm National Research Polytechnic University, 29 Komsomol'skii ave., Perm, 614990, Russia \\ ${ }^{5}$ State University of Management, Ryzanskyi prospect, 99109542, Moscow, Russia

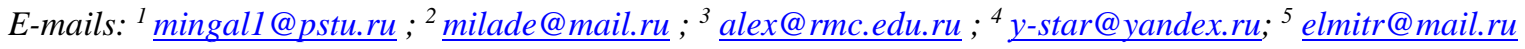

Received 18 September 2019; accepted 22 November 2019; published 15 December 2019

\begin{abstract}
The main problems of modern business are related to the processes of creating knowledge and introducing innovations, which form the basis of the "innovation economy". To keep positions in the market, modern enterprises and organizations need continuous creation and production of new products. A constant search for new technologies, methods of personnel management and methods for implementing projects is necessary to ensure sustainable development of the enterprises and business. The article proves a hypothes explaining the process of creating and stimulating innovation within the framework of modern enterprises and organizations and its relationship with the processes of knowledge creation and HADI-cycle. The main scientific research methods are bibliographic analysis, content-analysis, formal logic methods and methods of analogies. The verification with the help of formal logic methods showed the universality of the proposed model for the innovative enterprtnership. The result of this article indicates that the mechanism of interaction between the standard and non-standard cycle of creating new organizational knowledge in the organization management system allows to accelerate the process of creating and introducing innovations, increases the effectiveness of marketing and management in general and sustainability development of the enterprises.
\end{abstract}

Keywords: sustainability development; innovative enterprtnership; innovations and technology transfer; stimulating innovation; HADIcycle; processes of knowledge creation; knowledge conversion

Reference to this paper should be made as follows: Mingaleva, Zh., Deputatova L., Akatov N., Starkov, Y. Mitrofanova, E 2019. Application of HADI-cycle for providing sustainability of processes of knowledge and innovation. Entrepreneurship and Sustainability Issues 7(2), 1628-1640. http://doi.org/10.9770/jesi.2019.7.2(58)

JEL Classifications: O33, O34, M11, M13

\footnotetext{
* This research was supported by the project, which has received funding from the Ministry of Education and Science of the Russian Federation to Perm National Research Polytechnic University (2017-2019). Grant Agreement Number 26.6884.2017/8.9.
} 


\section{ENTREPRENEURSHIP AND SUSTAINABILITY ISSUES}

ISSN 2345-0282 (online) http://jssidoi.org/jesi/

2019 Volume 7 Number 2 (December)

http://doi.org/10.9770/jesi.2019.7.2(58)

\section{Introduction}

The modern economy is undergoing significant changes. Competitive organizations should take the initiative, act in accordance with the future needs of society and trends in the market, anticipate changes in society, thereby creating advantages over competitors (Lumpkin \& Dess, 2001). The reactions to the problems that arise in a changing society are new types of knowledge and new ways of organizing their production, which can arise as generators of knowledge (Fogerberg et al., 2012).

In conditions of a low level of knowledge, in the absence of new ideas, enterprises will not generate innovations. "Creativity, innovation and divergent thinking are routinely expected to help people envision and implement alternative practices to the status quo" (Sandri et al., 2013; p.765). The innovative activity of organizations depends entirely on knowledge management and creativity. It is creativity that gives the most important applied implications for managing innovation (Brem et al., 2016). Structuring and defining the transformation of organizational knowledge makes it possible to more accurately pick up management tools for the organization's innovative potential. Innovative organizations support new ideas and create new knowledge more actively, creating a mechanism for the continuous development of new products, services or processes (Lumpkin \& Dess, 1996). Transformation of knowledge in the organization provides its value to its customers and helps to achieve a high competitive position in the market (Griffith et al., 2006).

However, there is considerable literature which attempts to define knowledge-based innovation and suggests that the process of innovation itself relies heavily on innovation knowledge that is usually created and transferred or disseminated within a company, between companies, or between companies and innovators (Nonaka \& Kogut, 2009; Tehseen et al., 2019; Bublienè et al., 2019). R.M. Grant (Grant, 1996), D.F. Teece (Teece, 2000), Y. Li, X. Liu, L. Wang, M. Li and H. Guo (Li et al., 2009) observed correlation with innovation and creation of knowledge through its collection and use within the enterprise (Schulze \& Hoegl, 2008). R. Puente-Diaz explored the consequences of creative self-efficacy in the work domain (Puente-Diaz, 2015) and X. González, D. Miles-Touya and C. Pazó studied the worker training and innovation on the firm level (González et al., 2016).

\section{Theory and Hypotheses Development}

Studying the practice of competitive struggle in the modern economy shows that innovation, the development of new products and services involves extensive and intensive activities in the field of knowledge. "Research \& development has been identified as a key element to achieve competitive advantage, particularly in contexts of change and especially for technology-based companies" (Bigliardi \& Galati, 2014; p.157). The transformation of knowledge provides value to its customers and helps to achieve a competitive position in the market (Griffith et al., 2006). The organization creates a new mix of resources and products designed for the upcoming changes, opportunities and market entry, taking advantage of opportunities (Lumpkin \& Dess, 2001). Creativity and innovation are at the core of important outcomes such as economic and sales growth, the creation of new product (Puente-Diaz, 2015; Relich, 2015).

Innovative firms may have a tendency to support new ideas and novelty, and further increase the engagement in development of new products, services, or processes (Lumpkin \& Dess, 2001). They must be proactive, anticipate and act on future demands and needs in the marketplace, thereby creating first-mover advantage vis-a-vis its competitors (Lumpkin \& Dess, 2001). The development of new products and services involves extensive and intensive knowledge activities. New types of knowledge and new ways of organizing the production thereof may emerge as knowledge generators' response to the challenges posed by a changing society (Fogerberg et al., 2012). 


\section{ENTREPRENEURSHIP AND SUSTAINABILITY ISSUES}

ISSN 2345-0282 (online) http://jssidoi.org/jesi/

2019 Volume 7 Number 2 (December)

http://doi.org/10.9770/jesi.2019.7.2(58)

R. F. Hurley, G. T. M. Hult and M. Tomas found a correlation between high levels of innovation and a culture of learning (Hurley et al., 1998). This affects the use of knowledge in the workplace (Li et al., 2009). O.J. Sandri, S., Holdsworth and I. Thomas proved the importance of measuring the creative abilities of university graduates as an important part of the cycle between workplace expectations, graduates' learning outcomes, teaching and learning, and curriculum development during degree programs (Sandri et al., 2018). Organizations with innovative tendencies are more likely to exchange and use information (Williams \& Lee, 2009). In entrepreneurial firms that shared knowledge within the company, new knowledge and their distribution throughout the enterprise were created (Cohen \& Levinthal, 1990; Mavrina \& Mingaleva, 2017). "Previous researches of knowledge management chiefly focused on qualitative approaches, and largely stressed key success factors of knowledge management, such as the infrastructure of information technology, the design of the knowledge management system, deployment of motivation schemes, and the like" (Korposh et al., 2011; p.225).

Modern researchers test hypotheses and put forward concepts about the transformation of knowledge in organizations (Krenz et al., 2014; Chang et al., 2014; Felin \& Hesterly, 2007; Jian \& Wang, 2010). They study the role of international knowledge and the creation of new knowledge in multinational company subunits (Cantwell \& Piscitello, 2015; Pan \& Zhang, 2012). These studies have revealed the importance of cyclical phenomenon of knowledge management.

On the basis of theoretical approaches to the concept of knowledge transformation and introduction of innovations available in the modern scientific literature (the knowledge spiral of socialization, externalization, connection, and internalization is the core of discussions and researches), we have formulated a number of hypotheses describing the process of implementing and stimulating innovations through the concepts of the theory of knowledge.

Hypotheses

H1. The creation of innovation involves several successive stages in the transformation of existing knowledge. The mechanism for creating innovation consists of the following stages: the creation of personal knowledge, the creation of codified knowledge, the creation of competence knowledge, the creation of materialized knowledge.

H2. An innovative economy requires the creation of mechanisms that increase the accuracy of testing new ideas and accelerate the process of innovation. Such a mechanism is the HADI-cycle. HADI-cycle assumes the reverse order of passing the stages of transformation of existing knowledge.

HADI-cycle is a mechanism for introducing innovations. The mechanism of knowledge transformation in the process of implementing innovation activity on the basis of HADI-cycle application consists of the following stages: creation of materialized knowledge, creation of competence knowledge, creation of codified knowledge, creation of personal knowledge.

H3. HADI-cycle is the accelerator of idea verification, innovation in the enterprise. HADI - cycle helps to increase the effectiveness of the process of creating knowledge and innovation

\section{Method}

The main research methods were:

- content-analysis of scientific literature to identify information on the basic scientific approaches to the creation and transfer of knowledge in various areas of scientific, innovative and industrial activity;

- system analysis - to generalize and systematize information about the processes of creating and transferring knowledge and its transformation into innovation;

- structural analysis - to reflect the basic relationships between the elements and processes of creating and transferring knowledge and its transformation into innovation; 
ENTREPRENEURSHIP AND SUSTAINABILITY ISSUES

ISSN 2345-0282 (online) http://jssidoi.org/jesi/

2019 Volume 7 Number 2 (December)

http://doi.org/10.9770/jesi.2019.7.2(58)

- methods of formal logic - for the theoretical justification of hypotheses and their verification.

Theoretical and methodological verification of the formulated hypotheses was carried out on the basis of the approaches to the management of knowledge and innovations developed in modern science, the theories of individual creative action and innovation management, the theory of organizations and the social cognitive theory. We used the classification of the forms of knowledge of I. Nonaka and H. Takeuchi (Nonaka \& Takeuchi, 1995) the research of P.M. Leonardi and D.E.Bailey about the making implicit knowledge explicit in task-based offshoring (Leonardi \& Bailey, 2008), the approach to the creation of new knowledge in organizations of $\mathrm{H}$. Tsoukas (Tsoukas, 2009) and the PDSA cycle by W. Edwards Deming (Deming, 1986). Also we used the theoretical and practical results of our previous research (Mingaleva et al., 2016) and the quantitative method of the creation of new knowledge and upgrade current knowledge (Korposh et al., 2011).

\section{Results and Discussion}

H1. The creation of innovation involves several successive stages in the transformation of existing knowledge. The mechanism for creating innovation consists of the following stages: the creation of personal knowledge, the creation of codified knowledge, competence knowledge, the creation of materialized knowledge. Generation and reproduction of innovations is one of the key foundations for the development of organizations in the knowledge economy (Spender, 1996; Minbaeva et al., 2014). Creation of new knowledge, intellectual product consists of 4 stages: 1) creation of personal knowledge; 2) the creation of codified knowledge; 3) creation of competence knowledge; 4) creation of materialized knowledge (Korposh et al., 2011). The main stages of creating knowledge in the process of intellectual activity in turn form a system of circulation of knowledge, including with the external environment, where new knowledge is disseminated and where people get new information for expanding their personal knowledge (Figure 1).

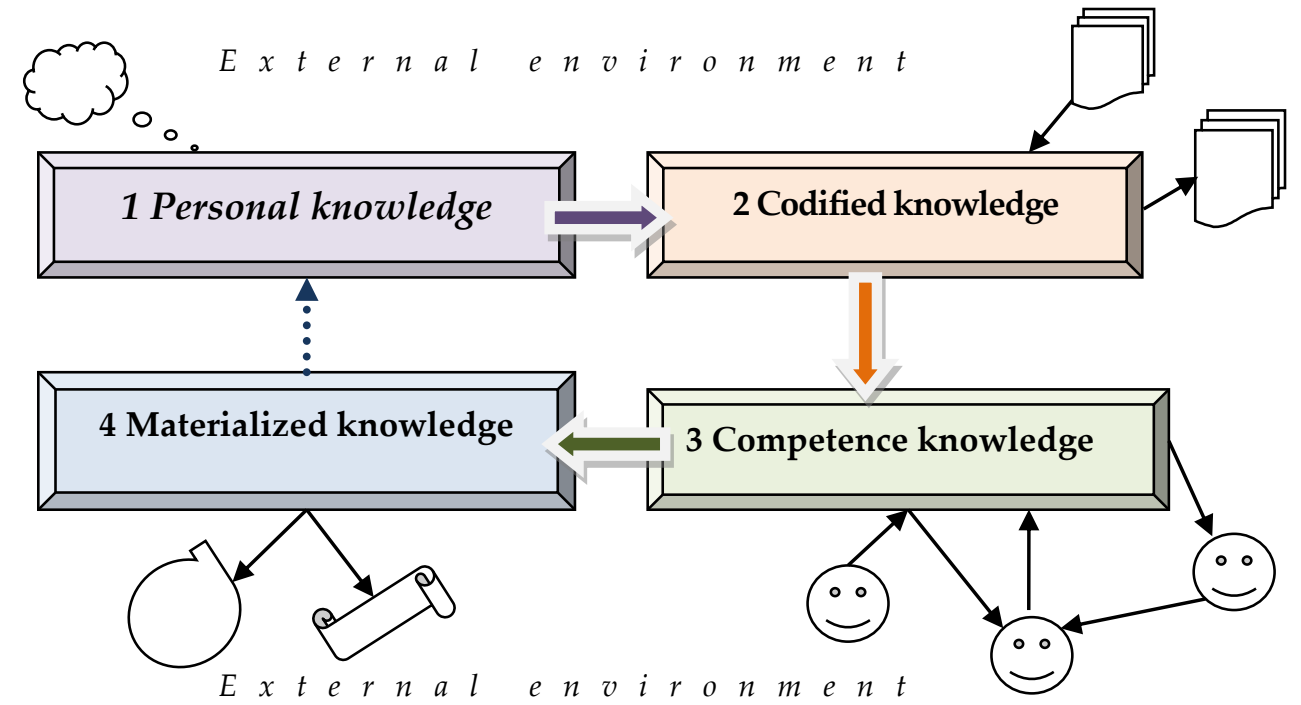

Fig. 1. The cycle of creating of new knowledge

Source: Autors (2019)

Personal knowledge is a person's knowledge, accumulated as a result of the formation of a creative personality, the creation of human capital. Codified knowledge is knowledge accumulated in the knowledge bases and databases of the enterprise, as a result of the coding and dissemination of personal knowledge. Competent knowledge is the knowledge of employees realized in the process of intellectual labor, accumulated as a result of 


\section{ENTREPRENEURSHIP AND SUSTAINABILITY ISSUES}

ISSN 2345-0282 (online) http://jssidoi.org/jesi/

2019 Volume 7 Number 2 (December)

http://doi.org/10.9770/jesi.2019.7.2(58)

the development and maintenance of social capital. Materialized knowledge is materialized new knowledge in products and services. The materialization of knowledge is the transformation of knowledge into information that can be transferred to other people for further use (Corredoira \& Preeta, 2015; Roper \& Hewitt-Dundas, 2015).

Stages of knowledge transformation provide the circulation of new knowledge in the company. Through the process of transformation, knowledge from the category of personalities through coding is transformed into an intellectual product capable of marketing. The transformation of knowledge is due to the intellectual work of man. The process of transformation of existing knowledge in the creation of new knowledge begins with a comprehension of the problem and determination of ways, methods and tools for its solution (Otsuki \& Okada, 2009 ). Awareness of the idea and the possibility of realization is already a new personal knowledge. Creation of a drawing, technical documentation of a new product, work schedule, etc. is a newly created codified knowledge. The implementation of new activities and the development of new skills of innovation are the competence knowledge of the enterprise or organization. The end result of intellectual and material labor is a new product. A new design solution, innovation is a newly created materialized knowledge.

In turn, these four groups of knowledge include specific types of knowledge, which also differ in the way they are obtained and how they are fixed. Figure 2 shows examples of the content of personal, codified, competence and materialized knowledge.

\begin{tabular}{||c||c||}
\hline \hline Personal knowledge: & Codified knowledge: \\
Personal opinion. & Declarative knowledge. \\
Common sense. & Statutory knowledge. \\
Collective knowledge. & Knowledge that depends on the specific \\
Traditions of unknown origin. & position. \\
\hline \hline Materialized knowledge: & Competence knowledge: \\
Objective / scientific knowledge. & Procedural knowledge. \\
Technical solution, documentation. & Random learning. \\
Intellectual product. & Automatic knowledge. \\
Patent. & Practical knowledge. \\
& Irrelevant behavior. \\
\hline \hline
\end{tabular}

Fig. 2. Variety of knowledge in the organization

Source: Autors (2019)

Figure 2 illustrates the internal diversity of all types of knowledge, which together make up organizational knowledge. Organizational knowledge exists in any organization always.

H2. An innovative economy requires the creation of mechanisms that increase the accuracy of testing new ideas and accelerate the process of innovation. Such a mechanism is the HADI-cycle. HADI-cycle assumes the reverse order of passing the stages of transformation of existing knowledge.

In practice, to accelerate the process of approbation of a new idea, the enterprise uses the HADI-cycle (Mingaleva \& Deputatova, 2017). Four letters mean four words - "Hypothesis" - "Action" - "Data" - "Insights". This means testing the hypothesis through an action, with the subsequent collection of analytical information and the formulation of the relevant conclusions.

The HADI cycle is a cyclically repeated process of testing ideas that affect the improvement of key project projects, startups, businesses. These key indicators can be a message, the number of customers per month, the 


\section{ENTREPRENEURSHIP AND SUSTAINABILITY ISSUES}

ISSN 2345-0282 (online) http://jssidoi.org/jesi/

2019 Volume 7 Number 2 (December)

http://doi.org/10.9770/jesi.2019.7.2(58)

number of returning customers, the conversion of the landing, etc. Each project needs its set of key indicators. The hypothesis can be confirmed or not. Its takes about a week to test the hypothesis in IT companies and small businesses. In organizations and enterprises in other areas of activity, as well as at large enterprises, this period may be longer.

In order to test the feasibility and possibility of applying the HADI-cycle to innovation, we will disclose the content of its main components and the stages of its implementation.

PDSA cycle by W. Edwards Deming is taken as a basis of HADI-cycle (Deming, 1986; Moen \& Norman, 2009). The Deming's PDSA Cycle («Plan-Do-Study-Act») cycle is a cyclically repeating decision making process used in quality management (Deming, 1950; Ishikawa, 1985).

Stages of the HADI cycle. At the first stage of the HADI cycle, we generate a hypothesis that will improve the key indicator of the project, business. It is important that this hypothesis meets the SMART principle, that is, it is specific, measurable, achievable, relevant and time-bound. The hypothesis should solve the existing problem of the project and give a concrete result, which allows to improve the economic performance of the organization. For example: we assume that if we introduce the technology of improving the engine to improve the quality of the car, it will increase the number of new customers by $\mathrm{X}$ per month.

By the second stage of the cycle, we mean a concrete action aimed at changing the characteristics of the project, which allows us to prove or disprove the hypothesis. For a certain period, it is necessary to implement this event. In the cases with our example, the specific action will be: the release of a car with a new engine, informing customers about new quality characteristics of the product, etc.

At the third stage of the HADI cycle, we begin collecting data on key indicators that will be affected by the change. In our example this is: the number of new customers.

At the last stage of the HADI cycle, analysis and summing up takes place. If the hypothesis is confirmed, we develop our actions and scale them to other similar projects.

The mechanism of knowledge transformation in the process of implementing innovation activity on the basis of HADI-cycle application consists of the following stages: creation of materialized knowledge, creation of competence knowledge, creation of codified knowledge, creation of personal knowledge.

The innovation process begins with practical implementation in the form of a new product, service, management method, mode of operation, etc. materialized knowledge, which must be implemented in the organization's activities (organize production). The application of HADI-cycle in the innovation activity of the enterprise (organization) allows to organize the mechanism of transformation of the whole complex of knowledge to support and accelerate the process of innovations introduction.

The order of knowledge transformation within the HADI-cycle is shown in Figure 3. 


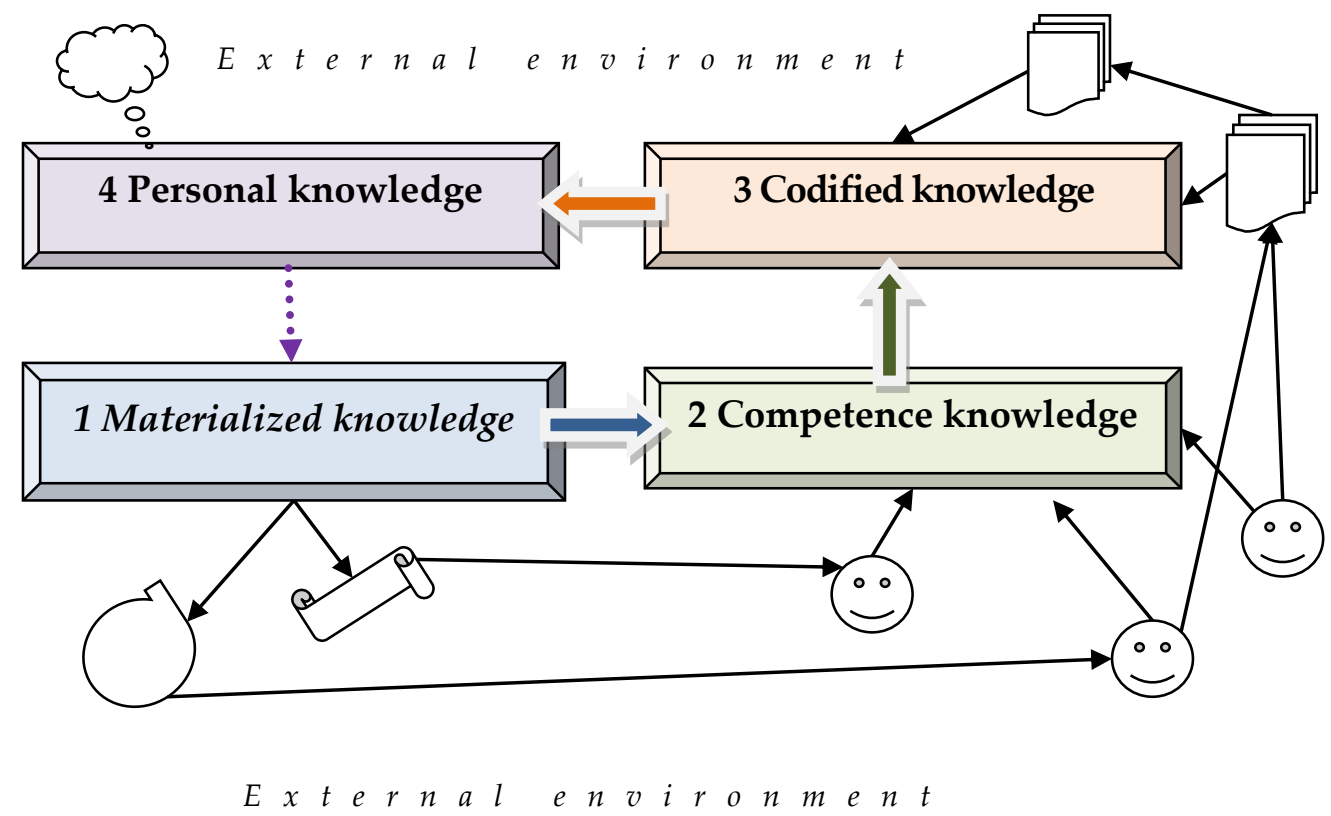

Fig. 3. HADI-cycle of knowledge transformation within the process of innovation implementation

Source: Autors (2019)

The cycle of introduction of innovation presented in Figure 4 has the reverse order of motion along the stages of transfer and transformation of knowledge in comparison with the standard cycle.

In the beginning, a new product is being created, the introduction of a new methodology, etc. - the practical implementation of materialized knowledge based on the prototype, the developed methodology, the patent, etc. (Dai \& Chen, 2016). The verification of this new product by actions in the external environment (on the market) allows to create competence knowledge about the applied value of this new product (service, mode of operation, management method) for consumers and other counterparties (Vidic, 2013). The collection of data from the external environment forms the database and the knowledge base of the enterprise (organization), creating and supplementing the codified knowledge.

Perception of statistical and analytical information on the results of the introduction of a new idea of improving the company creates personal knowledge. Human cognitive abilities based on the accumulation of personal knowledge can allow to form materialized knowledge, a new idea, innovation.

Thus, the introduction of innovation is accompanied by the creation of a new materialized, competence, codified and personal knowledge, and the HADI-cycle is a non-standard cycle of creating knowledge, moving counterclockwise.

H3. HADI-cycle is the accelerator of idea verification, innovation in the enterprise. HADI - cycle helps to increase the effectiveness of the process of creating knowledge and innovation

The system of management of innovations and intellectual labor, ensuring the continuity of the innovation process and aimed at creating a new intellectual product, materialized knowledge implies the transition from element to element according to the standard scheme. HADI-cycle, aimed at improving the key parameters of the organization's activities, involves moving from element to element in the opposite direction. The non-standard 
ENTREPRENEURSHIP AND SUSTAINABILITY ISSUES

ISSN 2345-0282 (online) http://jssidoi.org/jesi/

2019 Volume 7 Number 2 (December)

http://doi.org/10.9770/jesi.2019.7.2(58)

cycle is an important driving force for the standard cycle of creating new knowledge and innovations. At the same time, the speed, uniformity and rhythmicity of the passage of the basic cycle for the creation of new knowledge essentially depend on the number, as well as the synchronism and consistency of the individual HADI-cycles ensuring the implementation of projects at the enterprise (in the organization). The mechanism of interaction of the standard cycle of creating innovations and several non-standard HADI-cycles is shown in Figure 4.

The study showed that for the successful operation of the cycle of creating a new intellectual product and a continuous innovation process, it is necessary to have several HADI-cycles that affect competitive key performance indicators of the organization (enterprise). Larger enterprise has more diverse and diversified its activities. And the more complex and diverse the innovation processes are, the more HADI-cycles are needed to continuously support and accelerate innovation.

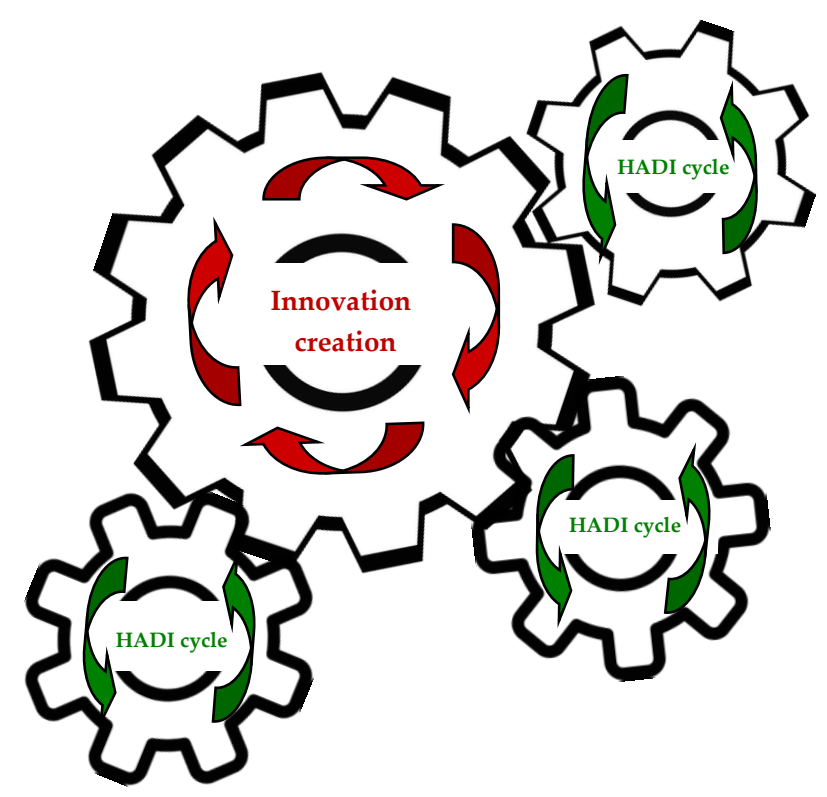

Fig. 4. The mechanism of interaction between the standard and non-standard cycle

Source: Mingaleva \& Deputatova, 2017, p.82

The mechanism of interaction between the standard and non-standard cycle of creating new organizational knowledge in the organization management system allows to accelerate the process of creating and introducing innovations, improves the manageability of personnel, creates conditions for the development of its intellectual capital, improves the quality of products and services, and increases the effectiveness of marketing and management in general. This mechanism also explains and confirms the need to create project or working groups to address the current problems of the organization (Danilina et al., 2016; García-Cruz et al., 2018). The proposed mechanism positively influences the intellectual work management system, accelerates the process of creating an intellectual product and innovative activity. 


\section{ENTREPRENEURSHIP AND SUSTAINABILITY ISSUES}

ISSN 2345-0282 (online) http://jssidoi.org/jesi/

2019 Volume 7 Number 2 (December)

http://doi.org/10.9770/jesi.2019.7.2(58)

\section{Conclusions}

The results of the research show the close interrelation and correlation between the main elements of the system of stimulating innovation in organizations and the competitiveness of organizations, manifested in the growth of their income. Theoretical and empirical analysis confirmed all hypotheses: the creation of innovation involves several successive stages of transformation of existing knowledge (H1); innovative economy requires the creation of mechanisms that help to improve the accuracy of testing new ideas and accelerate the process of innovation, which is the HADI-cycle. HADI-cycle assumes the reverse order of passing the stages of transformation of existing knowledge (H2); HADI-cycle is the accelerator of idea testing, innovation in the enterprise (H3).

The conclusions obtained as a result of the research make it possible to understand the dynamics of the process of creating and implementing innovations that ensure the growth of the competitiveness of organizations, the prospects for innovative development, the directions of action necessary to create new knowledge and their successful transfer within the organization to ensure reliable operation of the enterprise in a dynamic and competitive environment.

From a scientific and practical point of view, the study showed that managers of enterprises and organizations, research workers, innovators should be aware of the importance of the process of creating knowledge and its close connection with the innovation process. Managers of enterprises and organizations should contribute to creating a forming environment for creating an organization of a dynamic and effective process of creating knowledge.

The verification by using the methods of formal logic of the universality of the proposed model is confirmed by its applicability for building the system of knowledge management and innovations in enterprises and organizations of all types and spheres of activity.

\section{References:}

Bigliardi, B., Galati, F. 2014. The Implementation of TQM in R\&D Environments. Journal of Technology Management \& Innovation, 9, pp. 157-171.

Brem, A., Puente-Diaz, R. and Agogué, M. 2016. Creativity and innovation: State of the art and future perspectives for research. International Journal of Innovation Management, 20, 1602001. https://doi.org/10.1142/S1363919616020011

Bublienè, R., Vinogradova, I., Tvaronavičienè, M., Monni, S. 2019. Legal form determination for the development of clusters` activities, Insights into Regional Development, 1(3), pp. 244-258. https://doi.org/10.9770/ird.2019.1.3(5)

Cantwell, J. and Piscitello, L. 2015. New Competence Creation in Multinational Company Subunits: The Role of International Knowledge. World Economics, 38, pp. 231-254. https://doi.org/10.1111/twec.12175

Chang, J.J., Hung, K.P. and Lin, M.J.J. 2014. Knowledge creation and new product performance: the role of creativity R\&D. Management, 44, pp. 107-123.

Cohen, W. and Levinthal, D. 1990. Absorptive Capacity: A New Perspective on Learning and Innovation. Administrative Science Quarterly, 35, pp.128-152. https://doi.org/10.2307/2393553

Corredoira, R. and Preeta, B. 2015. Measuring Patent's Influence on Technological Evolution: A Study of Knowledge Spanning and Subsequent Inventive Activity. Research Policy, 44, pp. 508-521.

Dai, M. and Chen, Y. 2016. R\&D, Technology Imports and Innovation Capacity-Evidence from High-Tech Industry of China. American Journal of Industrial and Business Management, 6, pp. 24-32. https://doi.org/10.4236/ajibm.2016.61002 


\section{ENTREPRENEURSHIP AND SUSTAINABILITY ISSUES}

ISSN 2345-0282 (online) http://jssidoi.org/jesi/ 2019 Volume 7 Number 2 (December)

http://doi.org/10.9770/jesi.2019.7.2(58)

Danilina, E.I., Mingaleva, Z.A. and Malikova, Y.I. 2016. Strategic personnel management within innovational development of companies. Journal of Advanced Research in Law and Economics (JARLE-ASERS), 7, pp.1004-1013. https://doi.org/10.14505/jarle.v7.5(19).06

Deming, W.E. 1950. Elementary Principles of the Statistical Control of Quality, JUSE.

Deming, W.E. 1986. Out of the crisis. Cambridge, MA: Massachusetts Institute of Technology, Center for Advanced Engineering Study, p. 88.

Felin, T. and Hesterly, W.S. 2007. The knowledge-based view, nested heterogeneity, and new value creation: Philosophical considerations on the locus of knowledge. Academy of Management Review, 32, pp. 195-218.

Fogerberg, J., Fosaas, M. and Soprassart, K. 2012. Exploring the emerging knowledge base of 'The knowledge society'. Research Policy, 41, pp.1121-1282.

García-Cruz, J., Real, J.C. and Roldán, J.L. 2018. Managerial perceptions of employees' affective commitment and product innovation. Economics of Innovation and New Technology, 27, pp. 290-305. https://doi.org/10.1080/10438599.2017.1346163

González, X., Miles-Touya, D. and Pazó, C. 2016. R\&D, Worker Training and Innovation: Firm-Level Evidence. Industry and Innovation, 23, pp. 694-712.

Grant, R.M. 1996. Grand, toward a knowledge-based theory of the firm. Strategic Management Journal, 17, pp. 93-107.

Griffith, D.A., Noble, S.M. and Chen, Q. 2006. The performance implications of entrepreneurial proclivity: A dynamic capabilities approach. Journal of Retailing, 82, pp.51-62.

Hurley, R.F., Hult, G. and Tomas, M. 1998. Innovation, Market Orientation, and Organizational Learning: An Integration and Empirical Examination, Journal of Marketing, 62, pp. 42-54.

Ishikawa, K. 1985. What is Total Quality Control? The Japanese Way. Translated by David J. Lu. Englewood Cliffs; NJ: Prentice-Hall Inc, pp. 56-61.

Jian, Z.Q. and Wang, G.F. 2010. A Study of the Relationship among Organizational Learning, Knowledge Creation and New Product Development Performance. Proceeding of the 4 international conference on operation and supply chain management (ICOSCM 2010), 4 , pp. 80-84.

Korposh, D., Lee, Y.C., Wei, C.C. and Wei, C.S. 2011. Modeling the Effects of Existing Knowledge on the Creation of New Knowledges. Concurrent Engineering-Research and Applications, 19 (3), pp. 225-234. https://doi.org/10.1177/1063293X11418134

Krenz, P., Basmer, S., Buxbaum-Conradi, S., Redlich, T. and Wulfsberg, J-P. 2014. Knowledge Management in Value Creation Networks: Establishing a New Business Model through the Role of a Knowledge-Intermediary. Procedia CIRP, 16, pp. 38-43. $\underline{\text { https://doi.org/10.1016/j.procir.2014.01.006 }}$

Leonardi, P.M. and Bailey, D.E. 2008. Transformational technologies and the creation of new work practices: Making implicit knowledge explicit in task-based offshoring. Management Information Systems Quarterly, 32, pp. 411-436.

Li, Y., Liu, X., Wang, L., Li, M. and Guo, H. 2009. How entrepreneurial effect on knowledge management on innovation. Systems Research and Behavioral Science, 26, pp. 645-660.

Li, Y.H., Huang, J.W. and Tsai, M.T. 2009. Entrepreneurial orientation and firm performance: the role of knowledge creation process. Industrial Marketing Management, 38, pp. 440-449.

Lumpkin, G.T. and Dess G.G. 2001. Linking two dimensions of entrepreneurial orientation to firm performance: The moderating role of environment and industry life cycle. Journal of Business Venturing, 16, pp. 429-451. https://doi.org/10.1016/S0883-9026(00)00048-3

Lumpkin, G.T. and Dess, G.G. 1996. Clarifying the entrepreneurial orientation construct and linking it to performance. Academy of Management Review, 21, pp. 135-172.

Mavrina, I. and Mingaleva A. 2017. Entrepreneurship Education as a factor of regional economic development. In Insights and Potential Sources of New Entrepreneurial growth; Radovic-Marcovic, M.; Nikitovic, Z.; Zanadu, L.Ch., Eds.; Filodiritto Publisher: Bologna, Italy, pp. 370-381. 


\section{ENTREPRENEURSHIP AND SUSTAINABILITY ISSUES}

ISSN 2345-0282 (online) http://jssidoi.org/jesi/

2019 Volume 7 Number 2 (December)

http://doi.org/10.9770/jesi.2019.7.2(58)

Minbaeva, D., Pedersen, T., Björkman, I., Fey, C.F. and Park, H.J. 2014. MNC Knowledge Transfer, Subsidiary Absorptive Capacity and HRM. Journal of International Business Studies, 45, pp. 38-51.

Mingaleva, Z. and Deputatova, L. 2017. Stimulating of entrepreneurship through the use of HADI cycle technology. In Insights and potential sources of new entrepreneurial growth; Radovic-Marcovic, M.; Nikitovic, Z.; Zanadu, L.Ch., Eds.; Filodiritto Publisher: Bologna, Italy, pp. 72-85. ISBN 978-88-95922-84-3.

Mingaleva, Z., Deputatova, L. and Starkov, Y. 2016. Values and norms in the modern organization as the basis for innovative development. International Journal of Applied Business and Economic Research (IJABER), 14, pp. 124-133.

Moen, R. and Norman, C. 2009.The History of the PDCA Cycle. Proceedings of the 7th ANQ Congress Tokyo 2009 , September 17.

Nonaka, I. and Kogut G. 2009. Tacit knowledge and knowledge conversion: Controversy and advancement in organizational knowledge creation theory. Organization Science, 20, pp. 635-52.

Nonaka, I. and Takeuchi, H. 1995. The knowledge-creating company. Oxford University Press.

Otsuki, A. and Okada, K. 2009. Construction of Optimized Knowledge and New Knowledge Creation Support Tool, Agent and Multiagent systems: technologies and applications, Proceedings, 5559, pp. 500-513.

Pan, J. and Zhang, J. 2012. The Empirical Study on the Influence of Multinational Corporations' R\&D Investment on China's High-Tech Industry Innovation Ability. Forum on Science \& Technology in China, 1, pp.30-36.

Puente-Díaz R. 2015. Creative Self-Efficacy: An Exploration of Its Antecedents, Consequences, and Applied Implications. Journal of Psychology, 150, pp.175-195. https://doi.org/10.1080/00223980.2015.1051498

Relich, M. 2015. Knowledge creation in the context of new product development. International Scientific Conference on Knowledge for Market Use - Women in Business in the Past and Present, pp. 834-847.

Roper, S. and Hewitt-Dundas, N. 2015. Knowledge Stocks, Knowledge Flows and Innovation: Evidence from Matched Patents and Innovation Panel Data. Research Policy, 44, pp. 1327-1340.

Sandri, O., Holdsworth, S. and Thomas, I. 2018. Assessing graduate sustainability capability post-degree completion: Why is it important and what are the challenges? International Journal of Sustainability in Higher Education, 19 , pp. 2-14. https://doi.org/10.1177/0973408218792127

Sandri, O.J. 2013. Exploring the role and value of creativity in education for sustainability. Environmental Education Research, 19, pp. 765-778. https://doi.org/10.1080/13504622.2012.749978

Schulze, A. and Hoegl, M. 2008. Organizational knowledge creation and the generation of new product ideas: A behavioral approach. Research Policy, 37, pp. 1742-1750. https://doi.org/10.1016/j.respol.2008.07.002

Spender, J.C. 1996. Making knowledge: The basis of dynamic theory of a firm. Strategic Management Journal, 17, pp.45-62.

Teece, D.F. 2000. Strategies for managing knowledge assets: The role of firm structure and industrial context. Long Range Planning, 33, pp. 35-54.

Tehseen, S., Yafi, E., Sajilan, S., Ur Rehman, H., Masood Butt, S. 2019. Does ICT based network competence mediate strategic competencys impact on SMEs competitve advantage? An empirical evidence from Malaysian manufacturing SMEs. International Journal of Entrepreneurship (Print ISSN: 1099-9264; Online ISSN: 1939-4675), 23(2), 1939-4675-23-2-254

Tsoukas, H. 2009. A Dialogical Approach to the Creation of New Knowledge in Organizations, Organization Science, 20, pp. $941-957$. https://doi.org/10.1287/orsc.1090.0435

Vidic, F. 2013. Entrepreneurial Orientation (EO) and Knowledge Creation (KC). International Journal of Economic Sciences and Applied Research, 6, pp. 103-124.

Williams, C. and Lee, S.H. 2009. Resource allocations, knowledge network characteristics and entrepreneurial orientation of multinational corporations. Research Policy, 30, pp. 1376-1387. 


\section{ENTREPRENEURSHIP AND SUSTAINABILITY ISSUES}

ISSN 2345-0282 (online) http://jssidoi.org/jesi/

2019 Volume 7 Number 2 (December)

http://doi.org/10.9770/jesi.2019.7.2(58)

\section{Aknowledgements}

This research was supported by the project, which has received funding from the Ministry of Education and Science of the Russian Federation to Perm National Research Polytechnic University (2017-2019). Grant Agreement Number 26.6884.2017/8.9.

Short biographical note about the contributors at the end of the article (name, surname, academic title and scientific degree, duties, research interests):

Zhanna A. MINGALEVA is the Professor of Economics, Director of the Research Center for Sustainable Development and innovation processes PNRPU, professor of Department of Economics and business operation Perm National Research Polytechnic University (PNRPU, Faculty of Humanity). Leader more than 15 research scientific projects funded by Eurasia (EERC) Fund, Russian Humanitarian Scientific Fund, Moscow Public Scientific Fund, USA Agency for International Development (USAID), Ministry of Education and Science of the Russian Federation and other. Research interests: entrepreneurship and regional development; sustainability; innovation; intellectual capital; knowledge conversion; innovative enterprtnership.

ORCID ID: orcid.org/0000-0001-7674-7846

Lyudmila N. DEPUTATOVA is the lecturer and research worker of the Research Center for Sustainable Development and innovation processes of Department of Economics and business operation Perm National Research Polytechnic University. Research interests: entrepreneurship and regional development; intellectual capital; knowledge conversion; innovative enterprtnership. Research interests: entrepreneurship; innovation and small firms; staff motivation; generation and implementation of innovations; organizational knowledge. ORCID ID: orcid.org/0000-0003-0880-8373

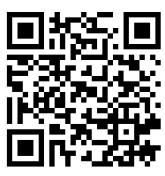


ENTREPRENEURSHIP AND SUSTAINABILITY ISSUES

ISSN 2345-0282 (online) http://jssidoi.org/jesi/

2019 Volume 7 Number 2 (December)

http://doi.org/10.9770/jesi.2019.7.2(58)

Nikolay B. AKATOV is the Professor of Economics, professor of Department of Management, Faculty of Humanity, Perm National Research Polytechnic University (PNRPU). He is engaged in research of theoretical and practical issues of managing the transition to selfdeveloping innovative organizations, the development of creative processes in assessing the credit rating of innovative projects, and creating the competency-building potential of managing high-tech industrial enterprises. Research interests: innovative enterprtnership; creative processes; innovative projects; intellectual capital; knowledge conversion; sustainability.

ORCID ID: orcid.org/0000-0002-4272-1055

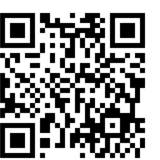

PhD Yurii V. STARKOV is the lecturer and researcher of Department of Economics and business operation, Faculty of Humanity, Perm National Research Polytechnic University. Research interests: statistics; economic modeling; entrepreneurship; sustainability, innovation. ORCID ID: orcid.org/0000-0002-4955-400X

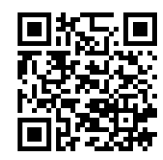

Elena MITROFANOVA is Professor of Department of HRM, State University of Management. Research interests: HRM, intellectual capital, staff motivation.

ORCID: orcid.org/0000-0003-4508-4458

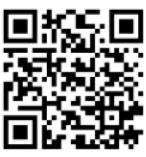

Copyright (C) 2019 by author(s) and VsI Entrepreneurship and Sustainability Center

This work is licensed under the Creative Commons Attribution International License (CC BY).

http://creativecommons.org/licenses/by/4.0/

(c) (i) Open Access 